\title{
Window on the World
}

This issue of Window on the World lists some of the key African institutions working on and off-line for economic and gender justice.

\section{African Policy Institutes and Think Tanks}

\section{African Center for Economic Transformation (ACET)}

http://acetforafrica.org

ACET defines itself as a 'think and do thank' engaging citizens and decision makers to promote policy and institutional reforms and drive economic and political transformation in Africa, with a vision that by 2025 all African countries will drive their own growth and transformation agendas, led by the private sector and supported by capable states with strong institutions and good policies.

Their activities include research and advocacy and engage citizens and decision makers, with a staff of 30 personnel, from 8 African countries and headquartered in Accra (Ghana).

\section{Foresight for Development}

http://www.foresightfordevelopment.org/

Foresight for Development is a knowledge-sharing platform to serve as a public archive and social network for foresight-related resources on the African continent. It has been developed by the NGO South African Node of the Millennium Project, with the support of the Rockefeller Foundation, within a broader international initiative of searchlight, horizon scanning and trend monitoring service - http://www.rockefellerfoundation .org/what-we-do/research-records. This initiative involves different organizations across the globe, including SID carrying out trend monitoring in the Greater Horn of Eastern Africa.

\section{African Leadership Institute (AfLI)}

http://www.alinstitute.org/default.aspx

The AfLI is a not-for-profit network, established in 2003, and aimed at building capacity and capability for visionary and strategic leadership across Africa. Through its activities and programmes, AfLI promotes the importance of good leadership and governance, be it in business, government or civil society and nurtures the leadership talents of high potential Africans in the 25-40 age range, who would constitute the next generation 


\section{Window on the World}

of leaders. Key partners are: Oxford University (Templeton), University of Western Cape, Ghana Institute for Management and Public Administration, and Makerere University. Archbishop Desmond Tutu is Patron of the Institute.

\section{Centre for Democracy and Development (CDD)}

http://www.cddwestafrica.org

The CDD was founded in 1997 in London when Nigeria was under military law. Its first commitment was to facilitate a round table discussion on the democratic future of Nigeria. It currently engages in activities of strategic analysis, research and capacity building aimed at promoting democratic process, economic governance and development. It is headquartered in London, with offices in Abuja and Lagos.

\section{Institute of Economic Affairs (IEA)}

http://www.ieakenya.or.ke

The IEA is a civic forum working to promote informed debate on key policy issues both economic and political and to propose feasible policy alternatives in these areas.

Though its activities, the institute reviews policy, informs decision making and provides research backup to policymakers including members of parliament, with the overall objective of encouraging public participation and public awareness in the policymaking and promoting social justice and dignity for every citizen.

\section{The African Centre for Technology Studies (ACTS)}

http://www.acts.or.ke/

ACTS has been the first African independent think tank to apply science and technology to development. It was founded in 1988 as a non-governmental organization based in Nairobi, Kenya, and then in 1997 it changed its status to an international intergovernmental policy research and outreach institution. It is committed to strengthen capacity, and develop and influence policies for better livelihoods and sustainable development. Through its activities, ranging from research and capacity building to policy dialogues and knowledge sharing, the institute seeks to assert Africa in the application of science and technology to development and steer the continent from poverty and dependence on the West.

\section{Refugee Law Project (RLP)}

http://www.refugeelawproject.org

The Refugee Law Project was established in 1999 to provide legal aid to asylum seeker and refugees in Uganda, as a result of an extensive research project according to which refugees in Uganda do not always enjoy their rights in accordance with domestic and international law. Through its activities of consultancy, legal aid, training, research and advocacy, the RLP aims at providing rights protection to refugees and forced migrants, seeks to empower them and their communities and at the same time tries to influence the national and international debate on migrant's rights, justice and peace.

\section{African Transitional Justice Network}

http://www.transitionaljustice.org.za

It was established in 2004 and was funded by the International Development Research Centre to promote transitional justice research in Africa and to assure that transitional justice agenda in Africa is locally informed and owned. Key activities include the development of research capacity, the building of transitional justice content knowledge, and the creation of spaces for practitioners and researchers to share experiences, expertise and lessons learned. A network listserv has been created to connect individuals working globally in the field of transitional justice.

\section{African open source web portals}

\section{Ushashidi}

http://www.ushahidi.com

Created in 2008 as a web resource space to map and report about violence as well as peace efforts in Kenya in the post-election period, it has 
shifted from being a group of volunteers to becoming a focused organization with a wide range of expertise from software development to human rights. Ushahidi is today a tech company developing free and open source software functional to information collection and interactive mapping. They provide technology-consulting services. Their clients include Al Jazeera, the World Bank, and the United Nations.

\section{Ihub - Nairobi's Innovation Hub for the Technology Community}

http://www.ihub.co.ke

Started in 2010 in Nairobi with the support of number of foundations, it is an open space for the technologists, investors, tech companies and hackers in the area. Although at first glance it may simply look like an Internet café, it is in fact a place where young inspiring and bright people work to develop new software, mobile applications and similar stuff. It works like an incubator, with the high lab at one floor, and the M-lab at the lower floor. In between, the funders work to support the creation of indigenous technology systems, looking for the best local technology developers and produce their projects in the M-lab. As a result, technology is not imported from elsewhere, but it is developed on the grown and Ihub has become in a short time a real center for technological innovation (Source: SID World congress 2011).

\section{KINU space}

http://www.kinu.co.tz/

KINU is a social enterprise seeking to impact on the Tanzanian technology and social landscape. The idea is that only by developing and pursuing a culture of co-creation and innovation can the establishment of a free and innovative environment that will be functional for the next generation of African to build products and services for the rest of the world be made possible. KINU aims at becoming a catalyst for growth and capacity building fostering participation and transfer of
The KINU website hosts a blog featuring news on youth, technology and innovation.

\section{Gender networks}

\section{Eastern African sub-regional support initiative for the advancement of women (EASSI)}

http://www.eassi.org

EASSI is a civil society organization, founded in 1996 after the Beijing Conference to monitor the commitments of Eastern African governments towards gender equality. It works in eight countries, namely, Burundi, Eritrea, Ethiopia, Somalia, Kenya, Rwanda, Uganda and Tanzania. The ultimate objective is a society where gender equality, social justice, peace and development can be enjoyed by all citizens. While the implementation of Beijing Declaration and Platform for Action is the key programme of the organization, new frameworks like the MDGs have been embraced and different area of concerns have emerged over the years, in particular: Women's rights and gender equality; Women's reproductive health and sexual rights; and Women in the peace process.

\section{African Women's Development and Communication Network (FEMNET)}

http://www.femnet.or.ke

FEMNET is a membership-based pan-African Network created in 1988 to advance African women's development, equality and other human rights.

Its approach comprises activities of communication, networking, advocacy and capacity building, aimed at increasing knowledge and data on women rights, identifying innovative ideas and strategies to advocate for women's rights at national, regional and international organizations, and mainstreaming gender in policy formulations, planning and programmes. FEMNET is currently working on five focus areas, namely: women's in leadership governance, women's economic empowerment; sexual and reproductive health; media freedom of information and use of ICTs, institutional strengthening of women's organizations and networks. It operates thought a regional secretariat in Nairobi (Kenya) 


\section{Window on the World}

and National Focal Point organizations in more than 30 countries in Africa.

\section{Tanzania Gender Networking Programme (TGNP)}

http://www.tgnp.org

TGNP is a civil society organization founded in 1993 and committed to the building of a transformative feminist movement. Transformative feminism means - beyond addressing the issue of gender balance and differences between women and men addressing globalization, class, race, gender identity, and challenging issues of imperialism as well as capitalism, patriarchy and discrimination of all kinds. Through activities of activism, lobbying and policy advocacy, analysis and research, training and capacity building, TGNP works to mainstream gender and pro-poor perspectives at all levels of Tanzanian society and look at poor women in marginal area as well as professional women in urban areas to support their process of self-empowerment and challenging patriarchy.

\section{Rwanda Women Network}

http://www.rwandawomennetwork.org

RWN is a national NGO born in 1997 with the aim of promoting and improving the socio-economic welfare of women in Rwanda. Over time, the organization has dedicated its efforts to strategies that empower women and has extensive experience in fostering women's participation and grassroots responses to community challenges. RWN works with various local and international partners, and plays a capacity building and facilitating role to a network of over 52 grassroots associations across the country.

\section{Somali Women's Study Centre}

http://www.somaliwomenstudies.org

Established in 2011, the Somali Wone's Study Center aims at enhancing Somali women's capacity and raise awareness around their condition and status in Somali society through research and advocacy. It is a response to the lack of knowledge and shortage of literature around the plight that Somali women have been going through after the collapse of the Somali governments that paved the way to militarized violence. The idea is that the production and dissemination of research material and publications, together with advocacy and grassroots activities, can serve as catalyst for positive change in the lives of Somali women, of all ages, in both rural and urban areas, within diaspora communities and minority groups, involved in the political arena as well as in civil society.

\section{Caucus for Women's Leadership}

http://www.kwpcaucus.org/

Caucus for Women's Leadership (formerly the Kenya Women's Political Caucus) is a national network committed to building women's leadership. After their restructuring and change of name in 2007, they have embraced a broader challenge of becoming a leading national and regional platform for women's empowerment. Through activities of lobbing, advocacy and capacity building, the organization seeks to establish platform of action at the grassroots where women can build their leadership skills. This is made possible by engaging women to increase their understanding of leadership, developing new skills and facilitating their participation in decision making.

Compiled by Angela Zarro 